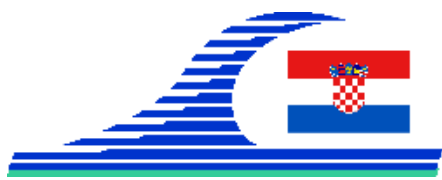

\title{
Innovative solutions for the enhancement of biodiversity on coastal infrastructures: case studies of artificial port nurseries and modular mooring reefs
}

\section{Matthieu LAPINSKI ${ }^{1}$, Pierre BOISSERY ${ }^{2}$, Renaud DUPUY-DE LA GRANDRIVE $^{3}$, Sylvain BLOUET ${ }^{3}$, Mathieu FOULQUIE ${ }^{3}$, Edouard CHERE $^{3}$, Martin PERROT ${ }^{1}$}

1. SEABOOST, 889 rue de la Vieille Poste, CS 89017, Montpellier Cedex 2, France. matthieu.lapinski@seaboost.fr

2. Agence de l'Eau Rhône Méditerranée Corse, Immeuble le Noailles, 62, La Canebière, 13001 Marseille, France. pierre.boissery@eaurmc.fr

3. Aire Marine Protégée Cap Agathoise, rue Alsace Lorraine CS2007, 34036 Agde Cedex, France.

renaud.dupuy@ville-agde.fr

\begin{abstract}
:
Coastal urbanization leads to the destruction and the fragmentation of intertidal and shallow subtidal habitats and the loss of associated ecological functions and ecosystem services. Primarily designed to achieve technical functions, maritime infrastructures also provide artificial environments for the establishment of benthic life and attract juvenile and adult individuals of numerous species. The lack of ecological considerations in coastal engineering, however, limits the potential for survival and growth of marine life both for mobile and sessile species. Thus, the paucity of marine communities in urbanized coastal zones has been described all around the world from Australia to the USA and also in the Mediterranean Sea. However, different recent projects have highlighted that ecological functions of maritime infrastructures such as seawalls, dikes, pontoons, can be enhanced working mainly on construction materials properties, water retention, and habitat complexity. Thanks to a constant knowledge development in urban marine ecology, different technical solutions begin to be available. Here we present two case studies in the Mediterranean Sea where solutions have been designed to improve ecological functions of different kind of maritime infrastructures: pile wharfs, riprap dikes and buoy mooring systems. If technical solutions are emerging, there are still great challenges ahead. Low-cost solutions adapted to different technical and ecological contexts have to be developed to promote large-scale ecological engineering programs with potentially significant ecological gains.
\end{abstract}

Keywords: Coastal engineering, Ecological engineering, Urban ecology, Green infrastructures, Biomimicry. 
Mediterranean rocky coasts:

Features, processes, evolution and problems

\section{Introduction}

Coastal urbanization is generally associated with the destruction and the fragmentation of intertidal and shallow subtidal habitats and the loss of associated functionalities (e.g. AIROLDI \& BECK, 2007). Between 0 and $-10 \mathrm{~m}$, at least $14.5 \%$ of the French south eastern Mediterranean shore have been covered by waterfront development and irreversibly destroyed (MEINESZ et al., 1991). The increasing number of artificial structures has recently provoked research on the possible ecological functions fulfilled by coastal infrastructures. Primarily designed to achieve technical features, different studies have begun to describe that coastal infrastructures can also support marine life such as artificial reefs can do. However, results of ecological monitoring are generally associated with poorer and different mobile and sessile communities in comparison to natural reference ecosystems (AIROLDI et al., 2005; CLYNICK et al., 2007; BURT et al., 2013; BOSCH et al., 2017). If ecological processes which occurred in marine urban zones are still poorly understood, different projects have emerged all around the world in order to improve ecological functions of maritime technical infrastructures (CHAPMAN \& UNDERWOOD, 2011; FIRTH et al., 2016; BOUCHOUCHA et al., 2016). Solutions mostly focused on the improvement of construction materials properties (porosity, rugosity, $\mathrm{pH}$ ), water retention in intertidal areas and habitat complexity (different scale for different stages of life). To date, most of the conducted studies highlighted those ecological functionalities of maritime infrastructures such as seawalls, breakwaters, wharfs, pontoons, can be enhanced through an ecological engineering approach. Here we proposed to illustrate this new field of coastal engineering through two ongoing case studies led in the French Mediterranean waters in order to improve ecological functions of different kind of coastal infrastructures: pile wharfs, riprap dikes and mooring systems.

\section{How to improve the nursery function for fish in the industrial Port of Marseille- Fos?}

\subsection{Technical and ecological context}

The first case study is conducted since 2014 on the French Mediterranean coast within the port of Marseilles-Fos and is still ongoing. This industrial port is the second biggest port of the Mediterranean Sea. Its multimodal activity (container, solid and liquid bulk, crude oil, ferry and cruise passengers etc.) requires many different types of maritime infrastructures. Timber pile wharfs and limestone riprap dikes are the most common of them. As in other studies (e.g. BOUCHOUCHA et al., 2016), initial monitoring conducted on the inner sides of this port have highlighted that juvenile stages of fish can be observed along pile wharfs and riprap dikes. However, diving observations also concluded that many ecological factors described in suitable Mediterranean nurseries 
Mediterranean rocky coasts:

Features, processes, evolution and problems

for coastal fish were absent (mainly gentle slope and micro-habitats as mentioned by HARMELIN-VIVIEN et al., 1995; VIGLIOLA \& HARMELIN-VIVIEN, 2001). Based on a biomimetic approach, two solutions have been designed to improve the nursery function of port' basins of Marseille-Fos for fish.

\subsection{Technical description of the solutions}

The first solution has been designed to improve micro-habitats complexity of vertical timber pile wharfs. It is bio-inspired by the Posidonia oceanica seagrass meadows, one of the most important nursery grounds in the Mediterranean Sea (BOUDOURESQUE et al., 2006). Thus, artificial seagrass is shaped and dimensioned according to the biological characteristics of the plant at low depth (up to $40 \mathrm{~cm}$ length for the artificial leafs). The "Roselières $@$ " module generates between each artificial leafs thousands of shelters for juvenile stages of fish along the vertical pile wharfs.

The second solution has been designed to improve micro-habitats complexity of rip-rap dikes composed of large (metric scale) limestone boulders and to reduce the important slope of such infrastructures in order to get closer to the characteristics of natural nurseries. It is bio-inspired by the symbiosis relation between long spine sea urchins and some tropical fish species which find protection between the spines (GOULD et al., 2014). A unitary “Oursin ${ }^{\complement}$ ” module looks like a giant long spine sea urchin. The semispherical module represents a total diameter of $1 \mathrm{~m}$ for a unitary volume of $0.26 \mathrm{~m}^{3}$. Spaces between each 161 long and flexible spines create on the extern part of the module numerous suitable micro-habitats for the protection of early life stages of marine fish. The inner part of the module offers a cavity where only little cryptic individuals of few centimetres can be found.

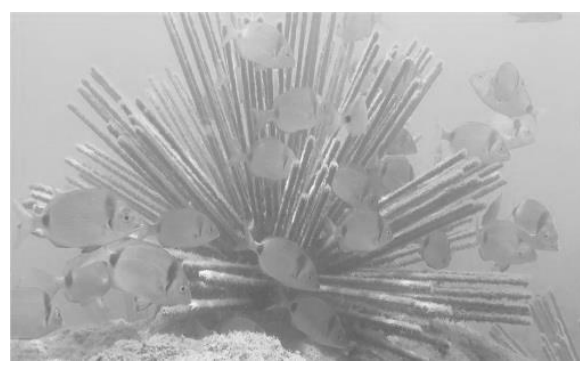

Urchins module used on riprap dikes

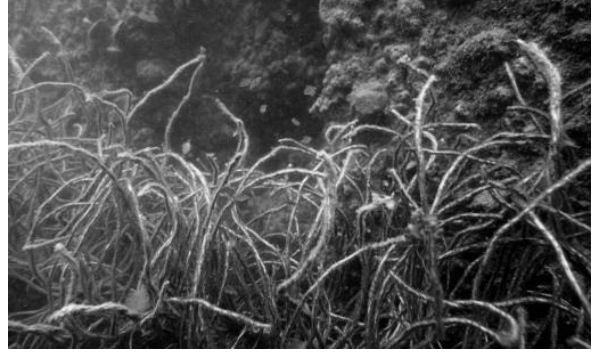

Seagrass module used on pile wharfs

Fig.1 Artificial micro-habitats designed to improve the nursery function for fish of the port' basins of Marseille-Fos 
Mediterranean rocky coasts:

Features, processes, evolution and problems

A total of 24 sections of $20 \mathrm{~m}^{2}$ of the Port of Marseille-Fos were eco-engineered with giant urchins and seagrass modules between $-1.5 \mathrm{~m}$ and $4 \mathrm{~m}$ depth. Thus, 240 linear meters of the port's infrastructures were equipped in May 2014 with both types of habitats, totalling respectively $480 \mathrm{~m}^{2}$ and $240 \mathrm{~m}^{3}$ of potential juvenile micro-habitats. The juvenile community of fish was studied in 2014 with Underwater Visual Census and video monitoring respectively through 132 and 64 replicates. As described in other studies (BOUCHOUCHA et al., 2016; MERCARDER et al., 2017), the micro-habitats complexification of the port infrastructures was associated with positive effects both on species richness and densities of juvenile stages of fish in comparison to non-equipped port infrastructures studied as control sites (LAPINSKI et al., 2015).

\section{How to improve the habitat function of mooring systems?}

\subsection{Technical and ecological context}

The second case study is also conducted on the French Mediterranean coast. Initiated in 2017, the associated project first aims to answer to a recurrent technical problematic of a Marine Protected Area: the annual deployment of beacons. Every year, hundreds of buoys have to be deployed in spring inside the MPA "Posidonia of Cap d'Agde" at 300 $\mathrm{m}$ of the coastline. The buoys line protects swimmers materializing the prohibited area for boats navigation. To date, small concrete units ( $<400 \mathrm{~kg}$ ) are generally used except inside sensitive habitats such as seagrass meadows. In winter, because mooring systems are not adapted to resist to important climatic events at low depth $(<15 \mathrm{~m})$, all the equipment is recovered through expensive and time-consuming campaigns. Moreover, during their annual deployment, as concrete mooring systems are "square-shaped" and without any cavities, their potential ecological values for marine life are reduced. However, some complex artificial hard substrates (breakwaters) have been locally described to host marine life (PASTOR et al., 2013). Based on a biomimetic approach and in order to benefit from the opportunity associated with the annual deployment of beacons in the MPA, new concrete moorings systems were developed.

\subsection{Technical description of the solution}

ECOMOOR $\complement$ solution was designed to achieve ecological functions targeting juvenile stages of fish and crustaceans. A unit of $170 \mathrm{~kg}$ made of Glass Fibre Reinforced Concrete concrete (without metallic armature to avoid chloride attacks) composes this modular system. Each mooring system is composed of four ECOMOOR@ units. Once assembled, the $0.7 \mathrm{~m}^{3}$ and one-meter high pyramid recreate a very complex artificial reef offering different sizes and shape of cavities and cracks and different orientation of substrate colonization. This four unit's configurations have been validated for this project in accordance with hydraulics models results. It allows the MPA stakeholders to let the concrete mooring system underwater all year long. From an ecological point of 
view, ECOMOOR@ systems will permit the settlement of a sustainable colonization over time. Potential recreated ecological functions would benefit both to summer and winter species. It is especially important for juvenile stages of fish where temporal segregation is well described in the Mediterranean Sea (MACPHERSON, 1998). 6 mooring systems composed by 24 ECOMOOR $^{\circledR}$ units have been already built. They will be immersed in September 2017 and monitored for two years in order to evaluate their ecological benefits in comparison to regular mooring systems used to date in the MPA "Posidonia of Cap d'Agde".
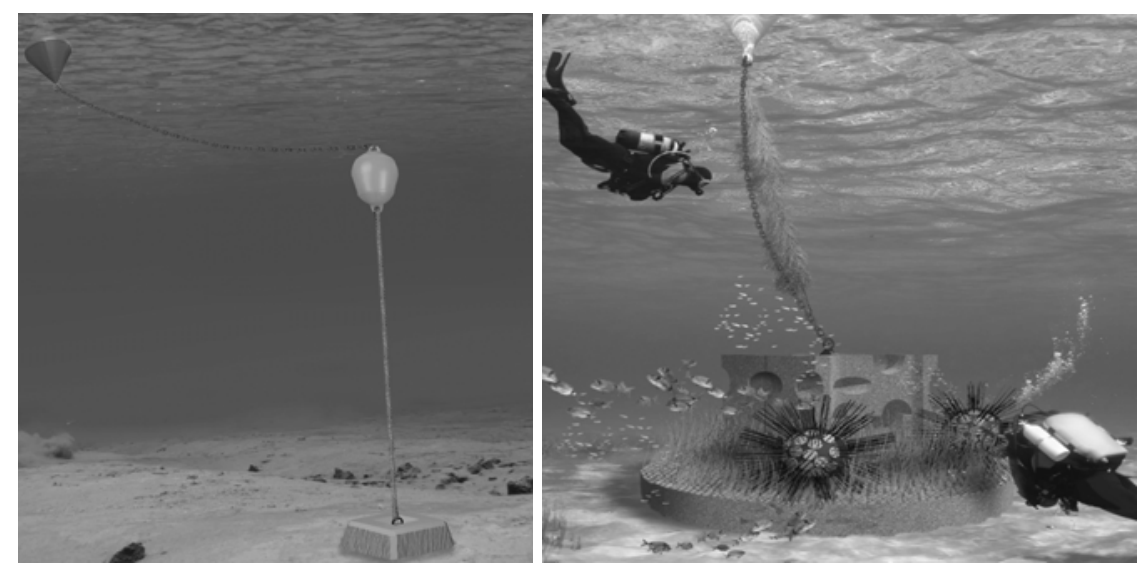

Fig. 2 Ecological functions support to date by regular concrete mooring systems (left) will be compared to ECOMOOR ${ }^{\odot}$ systems (right) by September 2017 in the MPA "Posidonia of Cap d'Agde" focusing on juvenile stages and concrete colonization.

\section{Conclusions}

The description of ecological processes in coastal infrastructures shows a recent and increasing interest in the scientific literature. However, results of ecological monitoring are generally associated with poorer and different mobile and sessile communities in comparison to natural reference ecosystems. Thus, different projects have emerged all around the world in order to improve ecological functions of a variety of technical infrastructures. Two ongoing case studies associated with port infrastructures and moorings were presented. This ecological engineering approach could be applied to any others immersed coastal infrastructures. Indeed, in a global change context associated with coastal fisheries collapse, eco-designed coastal infrastructures could fulfil a significant role in urbanized coastal ecosystems restoring altered ecological functions and ecosystems services. If ecological engineering represents an opportunity for a future sustainable coastal development, low-cost solutions deployable at large scale are needed to expect significant ecological benefits. 
Mediterranean rocky coasts:

Features, processes, evolution and problems

\section{References}

AIROLDI L., ABBIATI M., BECK M. W., HAWKINS S. J., JONSSON P. R., MARTIN D., MOSCHELlA P. S., SUNDELO A., THOMPSON R. C., ÅBERG P. (2005). An ecological perspective on the deployment and design of low-crested and other hard coastal defence structures. Coastal engineering, Vol. 52 (10), pp. 1073-1087. https://doi.org/10.1016/j.coastaleng.2005.09.007

AIROLDI L., BECK M.W. (2007). Loss, status and trends for coastal marine habitats of Europe. In Gibson R. N., Atkinson R. J. A., Gordon J. D. M. (editors), Oceanography and marine biology, Vol. 45., CRC Press-Taylor \& Francis Group, Boca Raton, Florida, pp. 345-405.

BOSCH N. E., GONÇALVES, J. M., TUYA F., ERZINI K. (2017). Marinas as habitats for nearshore fish assemblages: comparative analysis of underwater visual census, baited cameras and fish traps. Scientia Marina, Vol. 81 (2), pp.159-169. doi: http://dx.doi.org/10.3989/scimar.04540.20A

BOUCHOUCHA M., DARNAUDE A. M., GUDEFIN A., NEVEU R., VERDOITJARRAYA, M., BOISSERY P., LENFANT P. (2016). Potential use of marinas as nursery grounds by rocky fishes: insights from four Diplodus species in the Mediterranean. Marine Ecology Progress Series, 547, pp.193-209. doi: 10.3354/meps11641 BOUDOURESQUE C. F., BERNARD G., BONHOMME P., CHARBONNEL E., DIVIACCO G., MEINESZ A., PERGENT G., PERGENT-MARTINI C., RUITTON S., TUNESI L. (2006). Préservation et conservation des herbiers à Posidonia oceanica. RAMOGE pub. : 1-202, 204 p., ISBN 2-905540-30-3

BURT J. A., FEARY D. A., CAVALCANTE G., BAUMAN A. G., USSEGLIO P. (2013). Urban breakwaters as reef fish habitat in the Persian Gulf. Marine Pollution Bulletin, Vol. 72 (2), pp. 342-350. https://doi.org/10.1016/j.marpolbul.2012.10.019

CHAPMAN M. G., UNDERWOOD A. J. (2011). Evaluation of ecological engineering of "armoured" shorelines to improve their value as habitat. Journal of experimental marine biology and ecology, Vol. 400 (1), pp. 302-313. doi: 10.1016/j.jembe.2011.02.025

CLYNICK B. G., CHAPMAN M. G., UNDERWOOD A. J. (2007). Effects of epibiota on assemblages of fish associated with urban structures. Marine Ecology Progress Series, Vol. 332, pp. 201-210. doi: 10.3354/meps332201

FIRTH L. B., BROWNE K. A., KNIGHTS A. M., HAWKINS S. J., NASH R. (2016). Eco-engineered rock pools: a concrete solution to biodiversity loss and urban sprawl in the marine environment. Environmental Research Letters, 11(9), doi:10.1088/17489326/11/9/094015

GOULD A. L., HARII S., DUNLAP P. V. (2014). Host preference, site fidelity, and homing behavior of the symbiotically luminous cardinalfish, Siphamia tubifer (Perciformes: Apogonidae). Marine biology, Vol. 161(12), pp. 2897-2907. https://doi.org/10.1007/s00227-014-2554-z 
Mediterranean rocky coasts:

Features, processes, evolution and problems

HARMELIN-VIVIEN M. L., HARMELIN J. G., LEBOULLEUX V. (1995). Microhabitat requirements for settlement of juvenile sparid fishes on Mediterranean rocky shores. Hydrobiologia, Vol.300(1), pp. 309-320. https://doi.org/10.1007/BF00024471

LAPINSKI M., PERROT M., ROUANET E., ASTRUCH P., LE DIREACH L. (2015). Rapport technique de la phase de démonstration du pilote Ecorécifs, Programme GIREL, Montpellier, France, 123 p.

MACPHERSON E. (1998). Ontogenetic shifts in habitat use and aggregation in juvenile sparid fishes. Journal of Experimental Marine Biology and Ecology, Vol. 220(1), pp. 127-150. https://doi.org/10.1016/S0022-0981(97)00086-5

MEINESZ A., LEFEVRE J. R., ASTIER J. M. (1991). Impact of coastal development on the infralittoral zone along the southeastern southeastern Mediterranean shore of continental France. Marine Pollution Bulletin, Vol. 23, pp. 343-347. https://doi.org/10.1016/0025-326X(91)90698-R

MERCADER M., MERCIERE A., SARAGONI G., CHEMINEE A., CREC'HRIOU R., PASTOR J., RIDER M., DUBAS R., LECAILLON G., BOISSERY P., LENFANT P. (2017). Small artificial habitats to enhance the nursery function for juvenile fish in a large commercial port of the Mediterranean. Ecological Engineering, 105, pp. 78-86. https://doi.org/10.1016/j.ecoleng.2017.03.022

PASTOR J., KOECK B., ASTRUCH P., LENFANT P. (2013). Coastal man-made habitats: potential nurseries for an exploited fish species, Diplodus sargus (Linnaeus, 1758). Fisheries research, 148, pp. 74-80. http://dx.doi.org/10.1016/j.fishres.2013.08.014 VIGLIOLA L., HARMELIN-VIVIEN M. (2001). Post-settlement ontogeny in three Mediterranean reef fish species of the genus Diplodus. Bulletin of Marine Science, Vol. 68(2), pp. 271-286. 
Mediterranean rocky coasts:

Features, processes, evolution and problems 